\title{
Blackness, Colorism, and Epidermalization of Inferiority in Zora Neale Hurston's Color Struck: A Fanonian Reading of the Play
}

\author{
Mahshid Mirmasoomi
}

University of Tehran, Iran

Farshid Nowrouzi Roshnavand

University of Tehran, Iran

\section{Introduction}

The fragile status of marginalized groups in a society which is largely dominated by class, racial or sexual codes of discrimination has always been a point of interest for scholars of different fields. With the advent of postcolonial studies in the second half of the twentieth century and its rising popularity onwards, a great body of sociopolitical, cultural, and psychological research has been devoted to dealing with the covert and overt mechanisms through which the colonizer-colonized relationship is defined and regulated. Deeply concerned with the process of subalternization at work in the juggernaut of colonization, many postcolonial thinkers set out to know and prevent the great metamorphosis which was taking place in the colonized native's rich customs and traditions as a result of exposure to the "superior" culture of the dominant oppressing group. Franz Fanon, the French critic, was one of these postcolonial thinkers who singled out the discourse of psychoanalysis to analyze the hierarchical binarism of oppressor/oppressed, its workings and its detrimental damages to the integrity and wholeness of the colonized's psyche.

In Black Skin, White Masks, the first book to study the psychology of colonialism, Fanon touches upon the factors which subtly and gradually bring about an inferiority complex on the side of the colonized subjects and the severe implications this can have on their conception not only of the colonizer, but also of themselves (Sardar, $\mathrm{x}$ ). Fanon believed that the white-dominated society managed to maintain and perpetuate the patterns of subjugation through an all-encompassing propagation of negative racial stereotypes. Under the influence of this hegemonic discourse, the black subject was entrapped in a chain of signifiers which relentlessly depicted him as lascivious and dirty, and denigrated his traditions as 
inferior and destined to be "wiped out" by the so-called superior white culture. The result of this process of inferiorization is a subalternized figure "battered down" by the unbearable weight of the demeaning negative stereotypes about the "tom-toms, cannibalism, intellectual deficiency, fetichism, racial defects, slave-ships" (Fanon, 84-5). Fanon contended that the chromatic differences, as the most conspicuous outward indication of race, were manipulated by the dominant colonizers into the sole criterion by which human beings were judged, regardless of their sociopolitical or educational achievements. This, in effect, paved the way for the perpetual domination of the colonizer, who was allegedly blessed with the white color as the emblem of "Justice, Truth, Virginity" (ibid, 139), over the colonized, eternally damned with black "deviant" pigmentation which stood for "ugliness, sin, darkness, immorality" (ibid, 149). He believed that color-coded racism would ultimately bring about an inferiority complex in black-skinned subjects who found themselves unable to change the discriminatory status quo. As ultimate agents ofpower andauthority, the white dominators would gradually push blacks into the internalization of the negative stereotypes of their skin color whichrepresented blackness as the symbol of vice and depravity. According to Fanon, this would finally result in blacks' self-hatred and their ensuing efforts to emulate and behave like powerful whites, a process which he called epidermalization of inferiority. The process of epidermalization is also evident in African American community, where the degrees of blackness or whiteness have turned into the touchstone of granting or denying advantages, a hierarchical system which is called colorism in the sociological discourse.

This paper aims to apply concepts of epidermalization of inferiority and colorism to Zora Neale Hurston's play Color Struck. The literature review section of the paper considers the body of research devoted so far to the process of identity construction and the way individuals come to view themselves through the prism of others' perception.

\section{Literature Review}

Identity construction is a complicated and unending process out of which will never come out a finished, coherent entity. In other words, identity is "the problematic process of access to an 'image' of totality" which is only "an appurtenance to authority and identity" and not the appearance of a reality. As a result, the process of identity construction is wholly dependent upon "the negation of any sense of originality and plentitude" and the subsequent process of displacement and differentiation which always renders identity "a liminal reality" 
(Bhabha, $\mathrm{xxx}$ ). This view of identity construction can also be taken into account in the light of the school of phenomenology which contends that consciousness is always 'consciousness of' (Yancy, 220). In a similar vein, William James maintains that the body image, that is, those aspects of the self that we come to recognize first, is among the major constituents of the self and remains crucial throughout life; if one's bodily features are evaluated positively, the influence on one's self is also positive. Nevertheless, if society dismisses certain physical attributes, it is more likely that negative feelings about the self will arise (Thompson and Keith, 340).

Likew ise, Charles H. Cooley, a proponent of the symbolic interactionist paradigm, introduces the notion of "looking-glass self" which holds that self-concepts are gradually formed as one's reflections of and reactions to others' evaluations in every environment.In the process of forming the "looking-glass" self, individuals first imagine how they may look in the presence of other individuals. Second, they imagine others' appraisals of that appearance; and eventually, they start to develop some kind of self-perception or self-concept as a result of this process. Similarly, Harry Stack Sullivan posited the interpersonal theory and contended that the "significant others", i.e., those with enough power to reward and punish the subordinates, are responsible for the way people communicate and behave (Davis, Daniels and See, 75-6). Such views of identity construction are very similar to what Fanon addresses in Black Skin, White Masks, best reflected in his analysis of the development of the colonized's inferiority complex.

\section{Fanon's Epidermalization of Infe riority}

My body was given back to me sprawled out, distorted, recolored .... The Negro is an animal, the Negro is bad, the Negro is mean, the Negro is ugly. The white world, the only honorable one, barred me from all participation. A man was expected to behave like a man. I was expected to behave like a black man-or at least like a nigger. I shouted a greeting to the world and the world slashed away my joy. I was told to stay within bounds, to go back where I belonged. (Fanon, 86)

ThroughoutBlack Skin, White Masks, Fanon repeats that it is difficult, or better to say impossible, for a black subject to be just himself. As Fanon puts it, the black man always "must be black in relation to the white man" (83). Having been discriminated against and barred from all sociopolitical participation due to the exaggerated chromatic differences, the black subject always feels to be "overdetermined" by the contemptuous white gaze. Under constant erasure by the somatic regulatory epistemic pattern of whiteness (Yancy, 222), the black subject 
gradually comes to become conscious of his bodily schema and his blackness, a process which will turn into a negating activity at the end of the day (Fanon, 83). Encountering the rhetoric of the 'civilizing' group, experiencing great economic difficulties and being stripped of any local cultural originality, the colonized subject becomes culturally mummified and thus gradually comes to internalize, or 'epidermalize', the long-imposed notions of white superiority and black inferiority, hence the upcoming of an inferiority complex (4).

Indeed, under the coercive pressure of the white discourse, the black subject will end up in a complete situational neuros is which makes the negro run away from his own individuality and embrace alienation. As Fanon puts it, "the Negro, having been made inferior, proceeds from humiliating insecurity through strongly voiced self-accusation to despair" (43). Locked within what Edmund Husserl calls the "Natural Attitude" (Husserl, 2), the black subject wishes for "anonymity" and "invisibility", and carries within himself feelings of "shame", "self-contempt" and "nausea" (Fanon, 88). What happens in the end is "an amputation, an excision, a hemorrhage" of the black body (85); that is, the negro, undergoing a gestalt-switch, wishes to "denigrify" (83), "denaturalize" and "deracialize" himself (an inclination evident in blacks' desire to marry white or light-skinned people), as the result of the destructive process of self-interrogation and self-surveillance (52).

In short, Fanon contends that the white gaze interpellates the black subject as inferior and dirty, and this, in turn, compels the black subject to see himself only though the objectifying contemptuous white gaze. The result is a "surrogate" body which has no existence prior to the performance of white spectatorship; the black body becomes imprisoned in the white gaze and becomes ontologically pliable (Yancy, 222).

\subsection{Applicability of Postcolonial Studies to African Ame rican Experience}

The application of postcolonial theory to black America is often charged with simplifying and distorting the latter's distinctive features and concerns, since black America cannot strictly be considered to fit any standard pattern of colonial or postcolonial experience. However, it is undeniable that postcolonialism is at its core deeply sympathetic not only toward the colonized people but also toward outcasts of all kinds who have historically been regarded to be of little value and thus have been ignored (Young, 114). As Frantz Fanon asserted in his The Wretched of the Earth (1961), black people in the United States and Latin America encountered problems similar to those of Africans; and as Edward Said noted, resistance in the colonies, and opposition and protest in the metropolis, were 
interrelated and complementary expressions of the same emancipatory agenda. In fact, subjugation, cultural dispossession, social marginality and the resultant double consciousness of African Americans at the very heart of the First World War (an aftermath which is also called hybridity, syncretism, creolization or métissage) brought about the repercussions of the colonial contact in its most severe and challenging form; therefore, it is no exaggeration to say that African American experience in America vividly demonstrates and parallels various manifestations of postcolonialism (MacLeod, 51-5).

According to RanajitGuha, the history of the United States can best prove the fact that bourgeois capitalist culture ignores its allegedly noble achievements such as Democracy, Liberty, Rule of Law, Liberalism etc., when it comes to the expansion of capital and the colonial dominance. In colonial discourses, 'color', basically deemed to be at odds with Anglo-Saxon whiteness, symbolized not only racial difference but also cultural inferiority. The same discourse was employed by the United States which gained hegemony through the exercise of a color line that systematically expropriated the land and labor of indigenous peoples and nonwhite slaves, and forcibly externalized and subalternized them. So the postcolonial approach can be applied to the history and culture of the United States and divulge their contradictions (Cherniavsky, 85-6). The next part tries to depict the subtle process of colorism through which black Americans' epidermalization of inferiority is translated into sociopolitical, cultural and economic spheres.

\subsection{Colorism in African American Community}

If you're white you're right,

If you're brown stick around, but

If you're black stay back.

-Author unknown

The term colorism is used to describe the hierarchical system that assigns privileges to the lighter-skinned people over the darker-skinned ones within a community of color (Hunter, 176). Nonetheless, in general, the term not only deals with the skin color, but also addresses texture of hair, broadness of nose, eye color and fullness of lips. That is to say, European-shaped noses, blue eyes, and straight hair, as opposed to curly and kinky hair,are privileged in African American community (Thompson and Keith, 338-9). The prevalence and persistence of this system in African American community is the result of heinous, indelible memories of slavery and black Americans' unwholesome experiences in the racist white-dominated climate of post-Civil War era. Colorism has at the end of the day 
caused blacks segregating the members of their own community, discriminating against one another and assigning privileges merely on the basis of a Eurocentric discourse which prioritizes lighter skin complexions and Western facial features. So it is no exaggeration to say that by embracing this system, blacks have been naively manipulated by their oppressors into a discourse which aims to keep different strata of black American community obsessed with and divided overtrivia until they gradually become incapable of organizing and implementing effective emancipatory programs to promote the sociopolitical and economic status of blacks in the United States (Ogunleye, 636).

Particularly after the Civil War and Emancipation, chromatic differences came to play a more prominent role within the black American community as the mixedraces offsprings of interracial marriages acquired more power. Though mulattos were for the most part subjected to the same sociopolitical injustices as blacks and were deprived of basic civil rights, they sometimes received a special treatment from the dominant white society due to their white ancestry and thus were given privileges unavailable to monoracial blacks. As a result of their advantageous status, white-black biracials often allied with whites and separated themselves from blacks, a tendency that gave rise to a three-tiered racial system and introduced them as a "buffer class" between white and black races in some parts of the South. Trying to distinguish themselves from the darker-skinned people, the mulattoes founded separate communities in which light skin color functioned as the key to access. This means that dark-skinnedindividuals had to undergo a doublemarginalizing process: they were denied admission into the mainstream white society and at the same time were discriminated against by black-white biracials who deemed themselves as 'whiter' and thus superior (Khanna, 29-33).

Although the supercilious attitude of mulattoes caused much resentment among the dark-skinned individuals, mulattoes were for the most part admired and envied by blacks since they symbolized power, sociopolitical advantage and economic prosperity. This led to the internalization of a tacit rule among blacks that they more frequently than not came to embrace and implement either consciously or unconsciously: the more you become white, the more your life becomes rewarding.

The situation was even more complicated for dark-skinned women. Notions of skin color and physical attraction are closely connected and since physical attractiveness is something which is more expected of women across all cultures and societies, stereotypes of attractiveness and skin color are of grave importance for black women. Frequent exposure to demeaning stereotypes can irrevocably destroy a woman's sense of self. Diverse explanations can be offered here as to the considerable impact of negative stereotypes on black women's self-esteem. One is 
that the process of socialization for women takes place through the ir exposure to the evaluations of others and hence they are more vulnerable to negative stereotypes. Women tend to confirm their selves through evaluation from others more than men do. A second reason is that colorism and its related denominators are not the same for black men and women. For men, stereotypes of hypersexuality and criminality are associated with black skin color, while for women the question is attractiveness. Third, women often react more negatively to chromatic stereotypes because they have less control of their lives. This introduces a triple jeopardysituationfor black womenwhich involvesracism, sexism, and colorism (Thompson and Keith, 339).

In short, dark-skinned women were deemed as belonging to the bottom levels of the social ladder and thus were least marriageable and had fewer opportunities for education and career advancement. So it is quite inevitable for black women to become more color-conscious in such a discriminatory, sexist and racist atmosphere. The next section of the paper discusses Zora Neale Hurston's play Color Struck as a case study to demonstrate how epidermalization of inferiority, colorism and denigration of blackness work in African American community.

\subsection{Coloris m and Epidermalization of Infe riority in Hurs ton's Color Struck}

Oh, them half whites, they gets everything, they gets everything everybody else wants! The men, the jobs-everything! The whole world is got a sign on it. Wanted: Light colored. Us blacks was made for cobble stones. (Hurston, 44)

A play about the fear and insecurities surrounding black body (Benes, 54), Zora Neale Hurston's play Color Struck is the story of EmmalineBeazely, a darkskinned woman, who is morbidly jealous of her lover, John's, pursuit of lightskinned women which ultimately eventuates in the disintegration of their relationship. This four-scene play is set in a rural black section of Florida in the years between 1900 and 1920. The first scene takes place in a railway car in which Emma, John and other blacks are on their way to a cakewalking dance competition. Scenes two and three occur right before and during the dance contest and show how John's flirtatious behavior towards light-skinned Effie incites Emma's omnipresent jealousy and finally leads to their breakup. Scene four takes place twenty years later when John has returned from the north to make reconciliation with Emma only to find out that Emma had an out-of-wedlock affair with a white man and now has a sickly mulatto daughter, Lou Lillian. The play ends with the death of Lou Lillian which happens since Emma's dormant jealousy is actuated 
again in John's presence and she decides not to leave her light-skinned 'attractive' daughter with the man for whom she still has a feeling.

This play addresses the life of a character who epitomizes marginality and subalternization in every way: she is a dark-skinned, destitute, disenfranchised and rural woman and all these ultimately precipitate her final fragmentation and dislocation. In fact, Emma represents a figure who is dismissed both by the mainstream society (she is non-white) and also by the African American community (she is dark-skinned and is demoted to a lower status according to the defining criterion of colorism). The consequence is Emma's inferiority complex which creates a complicated condition for her: she internalizes and lives with a self-belittling identity and at the same time externalizes it by being morbidly obsessed with the color prejudice ubiquitous in African American community. The fact that Emma cannot find an emotional and social sanctuary in her rural black culture due to her dark skin color seems to be of grave importance in the eyes of Zora Neale Huston since she does not give any direct or indirect reference in the play to the stifling racism practiced by mainstream white society and merely touches upon the power of the discourse of colorism among black Americans (Krasner, 535-40).

Being doubly subalternized and existing in the "perilous territory of not-belonging" (Edward Said, qtd. in ibid, 544), Emma is an alienated, homeless and melancholic subject who is always on the brink of explosion due to constant pressure. She is so 'color struck' that she is totally blind to her own internalization of the discourse which has paralyzed her: she hates herself and even hates her own daughter. Lou Lillian is at first viewed by Emma as an instrument to boost her social status (Crawford, 2); nevertheless, later on she considers her as a rival with a light epidermis and thus a better chance of attraction and survival (Gubar, 234).

However, we should take this point into consideration that Emma was not the only color-struck character of the play. John is another practitioner of the discourse of colorism who with his philandering and flirtatious nature aggravates the equation. Emma's suspicion of his inclination toward light-skinned women is proved to be true by his behavior towards Effie. Though he is aware of Emma's sensitivity to and jealousy of "yellow" girls, he applauds loudly when Effie is dancing and even chooses her as his dance partner when Emma refuses to take part in the competition as a sign of protest. Even in the last scene of the play, we still find him fascinated with feminine mulatto beauty symbolized by Lou Lillian's long, straight hair (Krasner, 542-8). The important point here is that John, as a man, has been empowered by the black community to manage his colorism to his benefit since he has always enjoyed considerable latitude to choose (Benes, 59). All the same, the 
story is totally different for Emma for whom as a black woman, no social and economic upward movement is possible; that's the reason she appears mentally and even physically the same after twenty years in scene four (ibid, 64-5).

\section{Conclusion}

As mentioned earlier, the systematic marginalization of blacks in America did not stop with the Emancipation after which blacks encountered a more sophisticated process of misrecognition on a daily basis and suffered from the white America's general refusal to accept their humanity. According to Du Bois, this "disrespect and mockery, the ridicule and systematic humiliation" generated an "all-pervading desire to inculcate disdain for everything black" (12); that is to say, the weight of the racist stereotypes was so unbearable that gave rise to a malignant process of excessive self-surveillance and self-interrogation within African American psyche (Yancy, 219). Making things more complicated, whites declined to accept blacks as American citizens while simultaneously holding them to the accountabilities and responsibilities of citizenship.

Little by little, the American capitalist sociopolitical structure compelled blacks to internalize its negative stereotypes of their material conditions and their color of skin, which represented blacks as soul-less, poor, depraved, uncultured, irrational, and savage, and finally caused blacks' self-hatred and their efforts to live like the powerful bourgeois whites (Mocombe, 8). As Alexander G. Weheliye put it, the "look of the white subject interpellates the black subject as inferior, which, in turn, bars the black subject from seeing him/herself without the internalization of the white gaze" (qtd. in Yancy, 217). Amidst this racial discrimination, blacks were forced to choose between the forms prescribed by the power structure and the practice of their Otherized insecure African customs and as to be expected, they opted for the assimilation and reproduction of white America's norms in order to ameliorate their material conditions and achieve economic gain and respect, an elaborate procedure that resulted in African Americans' cultural amnesia and collective loss of recollection about the content and character of their history and customs. In other words, the desire to escape the negative stereotypes of blackness and gain a sense of self-worth within the sociopolitical structure pushed blacks to denigrate their social origins in the hope of obtaining recognition and respect from the mainstream American society, a process which eventuates in epidermalization of inferiority and colorism (Mocombe, 33-7). 


\section{References and notes:}

Beneš, Bc. Jan. Discourse on Sexuality in the Works of Zora Neale Hurston. Diss. Masaryk University: 2011.

Bhabha, Homi K.Fore word to the 1986 Edition. Black Skin, White Masks, by Frantz Fanon, xxi-xxxvii. London: Pluto Press, 2008.

Cherniavsky, Eva. "Subaltern Studies in a U.S. Frame.”Boundary 2, 23.2 (1996): 85-110.

Crawford, Margo Natalie. Dilution Anxiety and the Black Phallus. Columbus: The Ohio State UP, 2008.

Davis, Katheryn B., Maurice Daniels, and Letha A. Lee See. "The Psychological Effects of Skin Color on African Americans' Self-Esteem." Journal of Human Behavior in the Social Environment 1.2-3 (1998): 63-90.

Du Bois, W.E.B. The Souls of Black Folk. Ed. Brent Hayes Edwards. New York: Oxford UP, 2007.

Fanon, Frantz. Black Skin, White Masks. Trans. Charles Lam Markmann. London: Pluto Press, 2008.

Gubar, Susan. Racechanges: White Skin, Black Face in American Culture. New York: Oxford University Press, 1997.

Hunter, Margaret L. "If You're Light You're Alright: Light Skin Color as Social Capital for Women of Color." Gender and Society 16.2 (2002): 175-93.

Hurston, Zora Neale. "Color Struck.”In Zora Neale Hurston: Collected Plays. Eds. Jean Lee Cole and Charles Mitchell, 35-50. New Brunswick: Rutgers University Press, 2008.

Husserl, Ed mund. The Basic Problems of Phenomenology. Netherlands: Springer, 2006.

Khanna, Nikki. Biracial in America: Forming and Performing Racial Identity. Lanham, MD: Lexington Books, 2011.

Krasner, David. "Migration, Fragmentation, and Identity: Zora Neale Hurston's 'Color Struck' and the Geography of the Harlem Renais sance". Theatre Journal 53.4 (2001): 533-50.

MacLeod, Christine. "Black American Literature and the Postcolonial Debate". The Yearbook of English Studies 27 (1997): 51-65.

Mocombe, Paul C. The Soul-less Souls of Black Folk. Lanham: UP of A merica, 2009.

Ogunleye, Tolagbe. "Dr. Martin Robison Delany, 19Th-Century Africana Womanists: Reflections on his Avant-Garde Politics Concerning Gender, Colorism, and Nation Building." Journal of Black Studies 28.5 (1998): 628-49.

Sardar, Ziauddin.Foreword to the 2008 Edition. Black Skin, White Masks, by Frantz Fanon, vi-xx. London: Pluto Press, 2008.

Thompson, Maxine S., and Verna M. Keith. "The Blacker the Berry: Gender, Skin Tone, Self-Esteem, and Self-Efficacy." Gender and Society 15.3 (2001): 336-57.

Yancy, George. "Whiteness and the Return of the Black Body."The Journal of Speculative Philosophy 19.4 (2005): 215-41.

Young, Robert J. C. Postcolonialism: A Very Short Introduction. New York: Oxford UP, 2003. 


\title{
SUMMARY
}

\section{Blackness, Coloris m, and Epide rmalization of Inferiority in Zora Neale Hurston's Color Struck: A Fanonian Reading of the Play}

\author{
Mahshid Mirmasoomi \\ University of Tehran, Iran
}

\section{Farshid Nowrouzi Roshnavand \\ University of Tehran, Iran}

Ever since the first encounter between Columbus and Native Americans, the West has embarked on a subtle process of "Otherizing" non-whites as a means to maintain its hegemonic power over the subalternized groups. This strategy was also employed by the dominant whites in the United States, where a stereotypical representation of black slaves served as a justification for the institution of slavery. Through depicting blacks as irrational, lascivious, and eternally damned with a deviant pigmentation, the racis t representational strategy turned into a useful instrument to subjugate African slaves. Under such circu mstances, blacks, me rely due to their different skin color, were barred from having any major contribution to the sociopolitical or cultural spheres. Frantz Fanon was one of the critics concerned with the psychological effects of racism on the colonized subject. He believed racis $m$ would eventually cause an inferiority complex in black-skinned subjects who found themselves unable to effect any alteration in the discriminatory status quo; in other words, the white dominators would gradually compel blacks to internalize the negative stereotypes of their skin color which portrayed blackness as the symbol of vice and depravity. According to Fanon, this would finally bring about blacks' self-hatred and their efforts to behave like powerful whites, a process which he called epidermalization of inferiority. The process of epidermalization is conspicuous in African American community, where the degrees of blackness or whiteness have become the index of assigning or denying privileges, a hierarchical system which is called colorism. As a case study, Zora Neale Hurston's play Color Struck (1925) is analyzed in this paper to demonstrate the entrenched presence of coloris $m$ and epidermalization of inferiority in African American community, all of which attest to the preponderance of white ideological force and the coercion of blacks into the internalization of stereotypes as a means of survival.

Keywords: Stereotype, Epidermalization, Inferio rity Complex, Colorism, Color Struck 